\title{
Literary Cultures in/and Italian Studies
}

\section{Authors and Affiliations:}

Daragh O'Connell, University College Cork (daragh.oconnell@ucc.ie)

Beatrice Sica, University College London (b.sica@ucl.ac.uk)

\begin{abstract}
The article opens by considering how contemporary Italian Studies scholarship is situated in relation to the long-standing dominance of literary culture as a major disciplinary concern, and the persistence of traditionally conceived canons, questions, and methods. The authors discuss how the scope of literary research has expanded in recent years and become more enmeshed with sociological, political, and ideological enquiry. They review how previous definitions of literary cultures and practices have been refreshed with new theoretical and interdisciplinary approaches, and through transnational dialogues and collaborative modes of research. A diachronic survey discusses key innovations both in the study of canonical or 'high culture' literary phenomena - such as Dante, Leopardi, or Futurism -, and in engagements with previously overlooked writing in popular genres or media, or by socially marginalised authors. It concludes by reflecting on how literary studies is both critiqued and defended within current debates over the standing of humanities research within and beyond the academy.
\end{abstract}

Keywords: Italian literature; literary canon; literary theory; authorship; marginal writers; Dante Studies; impegno 


\title{
Literary Cultures in/and Italian Studies
}

\author{
Daragh O’Connell, University College Cork \\ Beatrice Sica, University College London
}

\begin{abstract}
The article opens by considering how contemporary Italian Studies scholarship is situated in relation to the long-standing dominance of literary culture as a major disciplinary concern, and the persistence of traditionally conceived canons, questions, and methods. The authors discuss how the scope of literary research has expanded in recent years and become more enmeshed with sociological, political, and ideological enquiry. They review how previous definitions of literary cultures and practices have been refreshed with new theoretical and interdisciplinary approaches, and through transnational dialogues and collaborative modes of research. A diachronic survey discusses key innovations both in the study of canonical or 'high culture' literary phenomena - such as Dante, Leopardi, or Futurism -, and in engagements with previously overlooked writing in popular genres or media, or by socially marginalised authors. It concludes by reflecting on how literary studies is both critiqued and defended within current debates over the standing of humanities research within and beyond the academy.
\end{abstract}

Keywords: Italian literature; literary canon; literary theory; authorship; marginal writers; Dante Studies; impegno

Literary cultures were the main constituent of Italian studies for a long time, as the discipline originated in the study of the Italian language and literature. ${ }^{1}$ Yet today the discipline of Italian studies is composed of many different things, literature being just one constituent part, a necessary - we still believe - but not no longer dominant, ingredient. This reflects, in certain respects, the status of literature itself. The idea of publishing today a 'History' devoted exclusively to Italian literature seems somewhat anathema. And yet, it was not uncommon in previous decades to place a marker down, set out the parameters and name a canon of distinctive literary writers (usually male). The last History of Italian Literature to be produced

\footnotetext{
${ }^{1}$ See David Robey, 'Italian Studies: the First Half', Italian Studies, 67.2 (2012), 287-99.
} 
in these islands was published in $1996 .^{2}$ As one would expect from such a compendium, and especially given its target readership of students, this history begins with the poetry of Francis of Assisi, before moving through the Duecento to its first substantial section dedicated to Dante, and from there touches on the literary notables, movements, and genres up to the 1980s. This was a major improvement of and upgrade on the previous history in the English language, which accorded scant space to post-war literature, and even less space to women writers of any period. ${ }^{3}$

The last major publication in English dedicated to an overarching fixing of Italian literary canonicity was The Oxford Companion to Italian Literature in 2002. ${ }^{4}$ The scope here was different to the previous History and was designed to be a more representative reference encyclopaedia. Expanded space is given to writers such as Belli and Carlo Porta, and the ages of so-called decline - the seventeenth and eighteenth centuries - are here appreciated without Romantic prejudices. Around a quarter of the substantive entries are given over to the twentieth century, which, as the editors state, 'for much of its course was often felt, inside Italy as well as abroad, to be the tail end of a great tradition' (p. viii). However, it is today inconceivable that such publications would be considered, not least because of the shift away from the purely literary within the discipline. The primacy of literature as the locus of study in Italian Studies is no longer feasible, and with good reason. ${ }^{5}$ The explosion of interest in different objects of enquiry and embrace of interdisciplinary forms, the turn to the visual, the material, the corporeal, and the transnational, have enriched, challenged, and rendered more complex, yet intellectually stimulating, the disciplinary norms. None of this downgrades the literary as a form of critical engagement, and consequently such changes are to be welcomed not solely for themselves, but also for how they impact and challenge the literary. In light of these considerations, what follows is a necessarily partial charting of certain trends and approaches in literary cultures. It cannot constitute, nor could it ever hope to, an exhaustive comment on the state of literary study - and there are, unfortunately, silences on some historical periods.

\footnotetext{
${ }^{2}$ The Cambridge History of Italian Literature, ed. by Peter Brand and Lino Pertile (Cambridge: Cambridge University Press, 1996).

${ }^{3}$ Ernest Hatch Wilkins, A History of Italian Literature, rev. by Thomas G. Bergin (Cambridge, MA: Harvard University Press, [1954] 1974).

${ }^{4}$ The Oxford Companion to Italian Literature, ed. by Peter Hainsworth and David Robey (Oxford: Oxford University Press, 2002).

${ }^{5}$ Signs of the change in critical stances were already apparent with the publication of The Cambridge Companion to Modern Italian Culture, ed. by Zygmunt G. Barański and Rebecca J. West (Cambridge: Cambridge University Press, 2002), which embraced a more complex cultural understanding not solely rooted in the literary.
} 
However, what follows endeavours to capture some of the richer seams of engagement with the literary, for all the problems such a term might entail.

Formalist approaches to literature, structuralism, and semiotic literary criticism changed indelibly our notion of text, giving us the clear sense of their construction within a whole system; cultural studies and feminist theories also changed our notion of text, with their attention to the political dimension of literature and their critique of the conceptions of the world and the ideological constructions that (Western) texts help(ed) to perpetuate. Through these lenses, literature became just one cultural construction among others, one that functions as a powerful tool to investigate the perceptions and values that are embedded in our imaginaries and societies. These changes to our understanding of texts, of what literature does, and of what we can do with it, are apparent in how literature is set in juxtaposition to other fields that provide context and comparison, such as history, philosophy, art, film, psychoanalysis, law, and any other we might think of. Therefore, with all these areas of enquiry with which literature can be usefully linked or juxtaposed, today in Italian Studies we may well ask: how and what are literary cultures doing?

\section{Our Losses are our Gains}

Literary cultures within Italian Studies are fine, in fact, doing very well, enjoying a great degree of freedom: indeed, literature today can be approached in virtually any way. All combinations of disciplines and angles are possible. Highbrows are always there, of course, ready to dismiss an approach not deemed appropriate, and to complain about the decadence of the strong interpretive traditions of the past, the false novelty of new methods, and the fall of high culture in the behemoth of the market. Long live highbrows: they make academic circles and debates thrive; and sometimes they may be right, too, in deploring certain trends or movements. However, in what they complain about, we cannot but recognise also the reason for today's freedom: where there is no one single truth, many truths become possible. Criticism - whether one likes it or not - is still feeling the effects of postmodernism and the end of grand narratives, which deconstructed overarching certainties, but also granted greater freedom in the approaches one can adopt. As Clodagh Brook, Florian Mussgnug, and Giuliana Pieri noted in a recent article:

As the world is $[\ldots]$ not actually divided up along disciplinary lines, those lines can be

$[\ldots]$ redrawn. [...] Interdisciplinarity arises [...] from a sceptical loss of confidence in 
modes and concepts, and from a postmodern experimental attempt to rethink common categories, unfixing boundaries that conceal domination or authority. ${ }^{6}$

The overview on literary cultures in Italian Studies that follows is based on academic research done and on publications that came out in the last decade, mostly in the UK and Ireland, but also in Italy, France, North America, and Australia. This overview is by no means exhaustive; it only aims to give an idea of the variety of approaches that can be adopted in Italian Studies when dealing with literary cultures and canons, and of the disciplines in whose company Italian literary cultures might find themselves today. The reasons why research and publications from the UK and Ireland have been given more weight here are not insular, but simply practical: given that the authors of this essay and the journal in which it appears are based in the UK and Ireland, and considering that the space for this overview was going to be limited, we thought that this was the most sensible approach. It should be noted that, for each category, we could only indicate a few titles, but there are, of course, many more: the panorama is even more varied than the one we have sketched here. Omissions should be forgiven in advance and not taken personally.

We think that this overview, however UK-Ireland oriented, is representative enough of the variety of approaches to literary cultures in Italian Studies today. Of course, national differences in academic traditions exist and should not be forgotten - even if they, too, are weaker than they used to be, due to the mobility of researchers and the numerous exchanges and collaborations between countries. We will come back to this at the end of the article. However, from the outset it is important to state that the literary cultures in these islands have greatly benefited from and been enriched by the mobility of researchers coming from continental Europe and North America to Ireland and the UK to take up academic posts or begin research positions. This cross-fertilisation of strands, trends, schools, and methodologies has made for a fascinating, at times exacerbating, literary conversation. It has, moreover, shaken previously held positions and contested canons across the centuries, offering up a more fluid, complex, and richer understanding of the literary and its variegated forms.

\section{Dante (Again?)}

\footnotetext{
${ }^{6}$ Clodagh Brook, Florian Mussgnug, and Giuliana Pieri, 'Italian Studies: An Interdisciplinary Perspective', Italian Studies, 72.4 (2017), 380-92 (p. 382). See also http://www.interdisciplinaryitaly.org/interdisciplinary-italian-teaching-challenge-connection/ [all online references in this essay were last accessed 15 February 2020].
} 
To get a sense of how literary cultures and literary criticism have evolved and responded to the multiplication of disciplinary fields of critical inquiry, oddly there is no better place to start than by touching on current trends and collaborations within Dante Studies, concurrently the most traditional subject area within the field of Italian studies, but arguably the most mutable and adaptable to changing critical stances. Equally one could bemoan the fact that such concentration on a figure like Dante and the avalanche of recent critical work on his oeuvre hardly constitutes a pressure point within the 'literary' field of Italian Studies, due to the fact that Dante Studies always seems to be in rude health, and gives the appearance of being able to survive all by itself as other areas or methodologies are cast aside. Yet this is only an appearance. In the pages of this journal Zygmunt Barański warned that contemporary dantismo finds itself in some difficulty:

national and 'campanalistic' prickliness, academic politicking, scholarly formation and lineage, linguistic deficiencies, individual ambition, the reluctance to question the contributions of leading figures, innate conservatism and hence an unwillingness to challenge prevailing attitudes, outside interference, and perhaps most significantly, that overpowering, debilitating accumulation of scholarship that can serve as a brake as we endeavour to move our teaching and our research. ${ }^{7}$

While such a warning has certain truths to it, and could equally be applied to almost any 'literary' field within Italian Studies, not just Dante, it is also undeniably true that recent years have witnessed what may be best described as a new radical collaborative approach to Dante. On the one hand, there has been a welcome steady stream of excellent monographs on Danterelated subjects which both contest previously held positions and enhance our understanding of Dante and his context - here one may think of recent work by Tristan Kay on the lyric tradition from which Dante draws and which he invigorates; the hugely important area of vernacular translation in Dante's time studied by Alison Cornish; Heather Webb's investigation of personhood in the Commedia; or Elena Lombardi's positing of woman as reader and interlocutor in the Trecento; to name but a few (and there are many others). ${ }^{8}$ On the

\footnotetext{
${ }^{7}$ Zygmunt G. Barański, 'On Dante’s Trail', Italian Studies, 72.1 (2017), 1-15 (p. 2).

${ }^{8}$ In order: Tristan Kay, Dante's Lyric Redemption: Eros, Salvation, Vernacular Tradition (Oxford: Oxford University Press, 2016); Alison Cornish, Vernacular Translation in Dante's Italy: Illiterate Literature (Cambridge: Cambridge University Press, 2011); Heather Webb, Dante's Persons: An Ethics of the Transhuman (Oxford: Oxford University Press, 2016);
} 
other hand, there has been a truly collaborative approach to Dante which has fostered jointly run seminars, lecture series, lecturae, and collaborative research projects and publications, which includes scholars from the UK, Ireland, Italy, and North America. This is partly fuelled by the commemorative buzz around marking anniversaries, most recently the 750 years since Dante's birth (2015), which will culminate with the septcentennial celebrations scheduled for 2021, but also there has been a disciplinary shift, and a genuine movement towards collaboration and dialogue, opening fresh areas of investigation.

In 2007 intimations of this shift were already apparent in the UK with the establishment of the Leeds Centre for Dante Studies by Claire Honess and Matthew Treherne, which continues to have as its focus the promotion of the study of Dante from a variety of disciplinary and methodological perspectives, both within the University of Leeds and beyond. Public outreach and student engagement (both undergraduate and postgraduate), alongside its research goals, set the agenda for the Centre, which also became the locus for the major project funded by the UK Arts and Humanities Research Council (AHRC), Dante and Late Medieval Florence: Theology in Poetry, Practice, and Society (2012-17), bringing together a team of researchers at Leeds and Warwick Universities to examine the connections between religious thought and practice in Florence in the period 1280 to 1300 , and Dante's poetry. ${ }^{9}$ In a seemingly more traditional vein, Robert Wilson and Claudia Rossignoli instituted the Lectura Dantis Andreapolitana. Now nearing its completion (the final three cantos of Paradiso are due to be read in April 2020), it is set to become the first complete Lectura Dantis of its kind held in the UK, and publications of the readings are projected in the coming years. What is fascinating about this set of lecturae is both its public outreach, ensuring that it has become an excellent tool for the teaching of Dante, and the fact that it brings together established scholars alongside early career researchers, Dantists from these islands, but also from Italy and North America - the result is a fascinating mix of approach and style. ${ }^{10}$ Since 2011 , University College Cork has held an annual Dante Public Lecture Series, which is currently in its tenth year. The series aims to bring experts, translators, specialists from other disciplines, and artistic

Elena Lombardi, Imagining the Woman Reader in the Age of Dante (Oxford: Oxford University Press, 2018).

${ }^{9}$ The are two volumes directly arising from the project: Reviewing Dante's Theology, ed. by Claire E. Honess and Matthew Treherne, 2 vols (Oxford: Peter Lang, 2013). See also: https://ahc.leeds.ac.uk/directory record/821/dante and late medieval florence theology in _poetry_practice_and_society.

${ }^{10}$ The University of St Andrews houses an excellent website for the lecturae, which includes video recordings of each of the readings: https://lecturadantisandreapolitana.wp.standrews.ac.uk. 
practitioners to discuss emerging trends, research avenues, adaptations, and appropriations around the figure of Dante.

Internationally also, the world of Dante Studies has greatly benefited from the initiative taken by Giuseppe Ledda and his colleagues at the University of Bologna with the establishment of the biennial Alma Dante conference in Ravenna, which will have its third iteration in 2021. The scope of the conference is truly international, collaborative, intergenerational, and brings together scholars from many countries - that it should be taking place in Italy demonstrates the new international dimension to the dialogue within Dante Studies. Equally, other dialogues around Dante have seen the establishment of the Re-Reading Dante's Vita nova project, with a subheading that shines the light on its true focus and methodology: 'a collaborative research project'. It involved researchers from University College Cork, University College London, and the Universities of Bristol, Cambridge, Leeds, Notre Dame, Oxford, Reading, and Warwick, and its meetings were held across the UK, as well as at the Notre Dame campus in Rome, between 2017 and 2019. ${ }^{11}$ Shorter, focused, collaborative workshops have also been a feature of recent trends, including 'Mediating Dante: A Multidisciplinary Conversation', organised at University College Cork by David Bowe and Federica Coluzzi in 2019. ${ }^{12}$

As stated above, a rich seam of publications continues in Dante Studies in Ireland and the UK, from critical editions and translations, to important collections of essays methodologically and historically more sensitive to the nuances and sensitivities in medieval culture. ${ }^{13}$ Chief amongst these is Dante in Context (2015), and its much needed

\footnotetext{
${ }^{11} \mathrm{https}$ ://rereadingdantesvitanova.wordpress.com/.

12 https://mediatingdante.wordpress.com/.
}

${ }^{13}$ A new English translation of Convivio is the most recent fruit of the translation trend: Dante, Convivio: A Dual-Language Critical Edition, ed. and trans. by Andrew Frisardi (Cambridge: Cambridge University Press, 2018). Nor should it be forgotten that the monumental Nuova edizione commentata delle opere di Dante, or NECOD (Rome: Salerno) continues apace. Under the general editorship of Enrico Malato, five volumes, in eight parts, of the projected seven final volumes are now in print, and comprise: Vol. I: Vita Nuova. Rime ed. by Donato Pirovano and Marco Grimaldi (2 parts, 2015-2019); Vol. III: De vulgari eloquentia, ed. by Enrico Fenzi, with Luciano Formisano and Francesco Montuori (2012); Vol. IV: Monarchia, ed. by Paolo Chiesa and Andrea Taborroni, with Diego Ellero (2013); Vol. V: Epistole. Egloge. Questio de aqua et terra, ed. by Marco Baglio, Luca Azzetta, Marco Petoletti, and Michele Rinaldi (2016); Vol. VII: Opere di dubbia attribuzione e altri documenti danteschi. 1: Il fiore e il Detto d'Amore, ed. by Luciano Formisano (2012); 2: Codice diplomatico dantesco, ed. by Teresa De Robertis, Giuliano Milani, Laura Regnicoli, and Stefano Zamponi (2016); 3: Le vite di Dante dal XIV al XVI secolo. Iconografia dantesca, ed. by Monica Berté, Maurizio Fiorilla, Sonia Chiodo, and Isabella Valente (2017). 
interdisciplinary essays on Dante's historical, cultural, and intellectual contexts. ${ }^{14}$ The volume also serves as a reminder of how literature invites collaboration with others, in this case with non-Dantists who write cogently and succinctly on such diverse areas as politics, law, gender relations, medicine, religion, architecture, art, and music, to name but a few of the areas expertly covered. In addition, Dante and the Seven Deadly Sins (2017) isolates the capital vices as structuring elements for the whole of the Commedia, offering fresh insights into medieval notions of vices and virtues; while Ethics, Politics and Justice in Dante (2019) offers new avenues into the ethical-political sphere of Dante's thought. ${ }^{15}$

Perhaps the example that best encapsulates this collaborative impulse, which both invites participation and innovates within the 'literary' field of Dante Studies, and speaks to the general themes adumbrated thus far, is the three-volume publication of the Cambridge Vertical Readings in Dante's 'Comedy'. ${ }^{16}$ The volumes had their origin in the a series of thirtythree public lectures held at the University of Cambridge between 2012 and 2016. Each speaker was asked to shake off previously held critical positions and invited to read the Commedia vertically: that is, to consider the three parts of the poem in parallel with one another under the umbrella of 'connumeration'. Many of the authors in the volumes, somewhat humorously, stated their disapproval with the method, and yet went on to offer original readings which enhance our understanding of Dante's poem. Other pieces are decidedly enriched by the vertical constraints put upon them - see, for example, Kenneth Clarke's reading of the 10s, in which he demonstrates the rich and allusive intratexuality of the rhyming of 'arte' and 'parte' across the three canticles. ${ }^{17}$ The result of the vertical readings is a surprising admixture of novelty, nuance, and critical acumen. Above all, it is the result of true collaboration.

\section{Across the Ages}

In Medieval and Early Modern Studies more broadly, the collaboration adumbrated above is equally present in numerous research initiatives and projects which embrace digital humanities and cross period boundaries. An example of this is the fascinating collaborative project,

\footnotetext{
${ }^{14}$ Dante in Context, ed. by Zygmunt G. Barański and Lino Pertile (Cambridge: Cambridge University Press, 2015).

${ }^{15}$ Dante and the Seven Deadly Sins, ed. by John C. Barnes and Daragh O'Connell (Dublin: Four Courts Press, 2017); Ethics, Politics and Justice in Dante, ed. by Giulia Gaimari and Catherine Keen (London: UCL Press, 2019).

${ }^{16}$ Vertical Readings in Dante's 'Comedy', ed. by George Corbett and Heather Webb, 3 vols (Cambridge: Open Book Publishers, 2015-2017).

${ }^{17}$ K. P. Clarke, 'Humility and the (P)arts of Art', in Vertical Readings, I, pp. 203-21.
} 
Petrarch Commentary and Exegesis, c. 1350-c. 1650 (2017-19), led by Simon Gilson, Federica Pich, and Guyda Armstrong. The project aims to reconstruct the corpus of early Italian Petrarch commentary and exegesis, by cataloguing the relevant materials and providing analysis in terms of genres, contents (including paratextual materials), and readerships in a variety of contexts - academies, courts, universities, coteries of scholars, the print shop. The project proposes to create a freely available, on-line census that will offer a searchable catalogue of Italian language commentaries and other main kinds of exegesis on Petrarch. ${ }^{18}$

It is equally true that the commemorative boom has also facilitated collaborative and single-authored exegesis on Boccaccio, clustered around the 2013 sexcentenary of his birth. ${ }^{19}$ Within medieval literary studies more generally, reception, book production and material culture, readers and reading, have all become staple modes of engagement. That the nature, scope, and approaches to medieval literature and literary communities is changing and contesting rigid canons is exemplified by a new generation of scholars who forcefully question notions of gender and canon in their work. ${ }^{20} \mathrm{~A}$ forthcoming conference at University College Cork in June 2020 has an apposite title in this regard, aiming to rethink the boundaries of cultural authority in the first centuries of Italian literature: 'Cinque Corone? Rethinking the Early Italian Canon'. Traditionally, the 'Tre corone' cluster of Dante, Petrarch, and Boccaccio in the early Italian literary canon has been particularly monumental and fixed, and their 'hypercanonical' texts have been treated as an unchanging, authoritative group from as early as the 1370 s, but they were by no means the sole producers of authoritative texts in thirteenthand fourteenth-century Italy. The new, expanded grouping of 'Cinque Corone', originally proposed by David Wallace, includes Catherine of Siena and Brigitte of Sweden, two women who produced significant bodies of work, had a major cultural impact on medieval Italy, and represent a different kind of canonisation. ${ }^{21}$ Discussion of an expanded group of 'crowns' permits medieval scholars to engage in broad conversation about the traditional Italian canon,

${ }^{18}$ Details on the AHRC-funded project at: https://warwick.ac.uk/fac/arts/ren/researchcurrent/petrarch/, and database at: https://petrarch.mml.ox.ac.uk/.

${ }^{19}$ See for example The Cambridge Companion to Boccaccio, ed. by Guyda Armstrong, Rhiannon Daniels, and Stephen J. Milner (Cambridge: Cambridge University Press, 2015). Rhiannon Daniels's monograph, Boccaccio and the Book: Production and Reading in Italy 1340-1520 (Oxford: Legenda, 2009), was indicative of the new approaches to Trecento auctores.

${ }^{20}$ See for example David Bowe, 'Versions of a Feminine Voice: The Compiuta Donzella di Firenze', Italian Studies, 73.1 (2018), pp. 1-14.

${ }^{21}$ Europe: A Literary History, 1348-1418, ed. by David Wallace, 2 vols (Oxford: Oxford University Press, 2016). 
alternative canons, the role of gender in the reading and constructing of this canon, the role of 'minor' authors and works in a literary landscape, and the role of critics and researchers in perpetuating, challenging, and rethinking notions of cultural authority. In taking up such discussions, the medieval field develops a problematisation of literary authority, and draws attention to the traditional invisibility of female or other marginal voices, that has been underway for some time among scholars of the fifteenth through seventeenth centuries, as evidenced in the innovative book series on 'The Other Voice in Early Modern Europe', which posits the (mostly) female voice at its very centre, through the publication of treatises, dialogues, plays, poetry, letters, diaries, and pamphlets. ${ }^{22}$ Not surprisingly, Italian literary culture plays a significant role here, and recent years have seen the publication of many hitherto ignored texts, with works by such authors as Barbara Torelli Benedetti and Leonarda Bernardi alongside the more familiar Vittoria Colonna. ${ }^{23}$ Moreover, scholarship in the field of women's writing in the Renaissance continues apace, informed by the seminal studies of Virginia Cox and others. ${ }^{24}$

Literary cultures are embedded in much of the scholarship of later ages. As with the late medieval case, early modern studies have greatly benefited from the commemorative boom and collaborative networks of scholars. In the interests of space, we can only signal some instances of this tendency. The most obvious has been recent scholarship on Ariosto: the volume Ariosto, the 'Orlando Furioso' and English Culture, for example, marks the fifth centenary of the publication of the first edition of the Orlando Furioso in 1516, and analyses the diffuse impact of the poem on English culture, from the Tudors to the present day. ${ }^{25}$ In

22 'The Other Voice in Early Modern Europe' series was first published from 1996 to 2010 with University of Chicago Press. The series moved to the University of Toronto Press until 2014, and since 2015 has been part of a co-publishing arrangement between Iter Inc. and the Arizona Center for Medieval and Renaissance Studies.

${ }^{23}$ Barbara Torelli Benedetti, Partenia, a Pastoral Play. A Bilingual Edition, ed. and trans. by Lisa Sampson and Barbara Burgess-Van Aken (Toronto: Toronto University Press, 2013); Leonarda Bernardi, Gentlewoman of Lucca, a Pastoral Tragicomedy, ed. and trans. by Virginia Cox and Lisa Sampson with Anna Wainwright (forthcoming); Vittoria Colonna, Sonnets for Michelangelo ed. and trans. by Abigail Brundin (Chicago: Chicago University Press, 2005).

${ }^{24}$ Verso una storia di genere della letteratura italiana. Percorsi critici e gender studies, ed. by Virginia Cox and Chiara Ferrari (Bologna: Il Mulino, 2012); and two more studies by Virginia Cox, The Prodigious Muse: Women's Writing in Counter-Reformation Italy (Baltimore: Johns Hopkins University Press, 2011), and Lyric Poetry by Women of the Italian Renaissance (Baltimore: Johns Hopkins University Press, 2013).

${ }^{25}$ Ariosto, the 'Orlando Furioso' and English Culture, ed. by Jane E. Everson, Andrew Hiscock, and Stefano Jossa (Oxford: Oxford University Press, 2019). 
addition, the collection reflects upon the ways in which successive editions and translations, examples of critical reception, rewritings, and adaptations in different media all helped to shape the evolving understanding of the poem. On a different tack, David Lines's Vernacular Aristotelian projects have helped to foster collaboration between various institutions: Vernacular Aristotelianism in Renaissance Italy (AHRC funded, 2010-14) linked two major UK centres for Renaissance Studies (at Warwick University and the Warburg Institute), ${ }^{26}$ while the next phase of research extended further, with a European Research Council (ERC) grant establishing ties with the University of Venice, Ca' Foscari, for work on Aristotle in the Italian Vernacular (2014-19). ${ }^{27}$ International, collaborative scholarship is the hallmark also of a recent Special Issue of Renaissance and Reformation, interrogating the cultural forms of comedy through Machiavelli, Ariosto, Aretino, Annibale Caro, Fernando de Roja, Della Porta, Pasquino, Niccolò Franco, and Bronzino. ${ }^{28}$ The foregoing examples do not do justice to the ongoing excellent collaborations, projects, and research into the 'literary' Renaissance, but offer a brief snapshot.

Though the literary scholarship of later centuries can be varied in size and quantity due to both the contingencies of the area of study, and also the fact that the Seicento and Settecento have traditionally not had a very strong voice on university curricula, nonetheless, scholarship in these areas is not insignificant. Canonical figures such as Vico continue to attract a great deal of critical engagement, though often subsumed into philosophical schools and tendencies. ${ }^{29}$ Where there is a 'lack', as in the case of these much-maligned centuries, perhaps there is also an opportunity for future directions in 'literary' Italian Studies. The dialogue between ages, however, is increasingly important within the literary realm, and one protean area of investigation is the nineteenth-century literary appropriation of eighteenth-century ideas. This is wonderfully exemplified in Martina Piperno's recent study Rebuilding Post-

\footnotetext{
${ }^{26} \mathrm{https}: / /$ warwick.ac.uk/fac/arts/ren/researchcurrent/vernaculararistotelianism.

${ }^{27} \mathrm{https}$ ://aristotleinthevernacular.org/news/. Collaborative and individual publications attached to this are: 'Aristotele fatto volgare'. Tradizione aristotelica e cultura volgare nel Rinascimento, ed. by David A. Lines and Eugenio Refini (Pisa: ETS, 2015), and the recently published Eugenio Refini, The Vernacular Aristotle: Translation and Reception in Medieval and Renaissance Italy (Cambridge: Cambridge University Press, 2020).

${ }^{28}$ Comedy, Satire, Paradox, and the Plurality of Discourses in Cinquecento Italy, ed. by Ambra Moroncini and Stefano Jossa, Special Issue of Renaissance and Reformation/ Renaissance et Réforme, 40.1 (2017).

${ }^{29}$ A pleasing antidote to this tendency was the recent article by David L. Marshall, 'Giambattista Vico, Aphorism, and Aphoristic Machines', The Italianist, 37.3 (2017), 32447; see also Riccardo Gasperina Geroni, 'Mito e origine: Vico nella letteratura italiana tra le due guerre', Italian Studies, 74.3 (2019), 278-87.
} 
Revolutionary Italy: Leopardi and Vico's 'New Science' (Oxford: Voltaire Foundation, 2018). In keeping with Leopardi, and entering fully into the Ottocento, the first complete English translation of the Zibaldone came out in 2013, the product of a seven-year project carried out at the Leopardi Centre at the University of Birmingham, ${ }^{30}$ while Paola Cori's recent study on the same text follows Leopardi's philosophical journey and traces the origin of a sensibility towards the ephemeral, the hyper-real, and the simulacrum, something that communicates with modernity, indeed, post-modernity. Indeed, Leopardi is one of those authors that goes well beyond their own time; thus, one also finds unusual contaminations and parallels made with his work. ${ }^{31}$ All of these works are informed by the collobarative and single-authored research inculcated by the Leopardi Centre, including Cosetta Veronese and Pamela Williams's The Atheism of Giacomo Leopardi, ${ }^{32}$ and Fabio Camilletti's two excellent monographs from 2013: Leopardi's Nymphs. Grace, Melancholy, and the Uncanny, and Classicism and Romanticism in Italian Literature. ${ }^{33}$

Recent publications in Ottocento studies have also addressed Verga, gothic literature, the tensions between the verbal and the visual, the theme of war and the image of soldiers (triggered by the centenary of World War I and broad investigations of this theme), and Italian Orientalism. ${ }^{34}$ Important studies of readership and printed media in the peninsula have also

${ }^{30}$ Giacomo Leopardi, Zibaldone, ed. by Michael Caesar and Franco D'Intino, trans. by Kathleen Baldwin, Richard Dixon, David Gibbons, Ann Goldstein, Gerard Slowey, Martin Thom, and Pamela Williams (New York: Farrar, Straus and Giroux; London: Penguin, 2013). ${ }^{31}$ Cori, Forms of Thinking in Leopardi's 'Zibaldone': Religion, Science and Everyday Life in an Age of Disenchantment (Oxford: Legenda, 2019). See also Cori, 'Ipnotismo e iperrealtà. Spunti per un dialogo tra Leopardi e il postmoderno', Italian Studies, 74.3 (2019), 260-77; Davide Messina, 'Blind Windows: Leopardi with Rothko', Nineteenth-Century Context, 41.1 (2019), 51-62; Alessandra Aloisi, 'Elogio dell'inoperosità: Agamben e Leopardi', Italian Studies, 72.3 (2017), 282-91.

${ }^{32}$ Veronese and Williams, The Atheism of Giacomo Leopardi (Leicester: Troubadour, 2013).

${ }^{33}$ Camilletti, Leopardi's Nymphs. Grace, Melancholy, and the Uncanny (Oxford: Legenda, 2013), and Classicism and Romanticism in Italian Literature (London: Pickering and Chatto, 2013).

${ }^{34}$ On Verga, see Selena Daly, 'Fallen Women in the Galleria: Giovanni Verga and the Nineteenth-Century Milanese Shopping Arcade', Italian Studies, 74.1 (2019), 44-56; Mattia Roveri, 'Drafting Soldiers: The Military in Giovanni Verga', The Italianist, 39.1 (2019), 119; Alessio Baldini, 'The Liberal Imagination of Giovanni Verga: Verismo as Moral Realism', The Italianist, 37.3 (2018), 348-68; Alessio Baldini, 'Putting the Self into Perspective: Fiction and Moral Imagination in Giovanni Verga', The Italianist, 35.3 (2015), 369-83. On the other areas mentioned in the text, see Fabio Camilletti, Guida alla letteratura gotica (Bologna: Odoya, 2018); Camilletti, The Portrait of Beatrice: Dante, D.G. Rossetti, and the Imaginary Lady (Notre Dame: Notre Dame University Press, 2019); L'image du soldat au XIXe siècle, ed. by Stefano Magni and Perle Abbrugiati, Special Issue of Italies 20 (2016); Barbara Spackman, Accidental Orientalists: Modern Italian Travelers in Ottoman 
appeared: The Formation of a National Audience in Italy, 1750-1890 (2017), explores how new modes of writing and performing, such as popular novels, treatises, newspapers, literary criticism, opera, theatre, and salon performances contributed to developing an Italian national cultural identity between the late eighteenth and the nineteenth centuries; while The Printed Media in Fin-de-Siècle Italy (2011), focuses on the production and consumption of books, magazines, and journals printed in Italy between 1870 and $1914 .{ }^{35}$

Another fruitful area of investigation is the thematically-driven, collaborative dialogue across the ages, usually with the literary text(s) as its object of concern. Fine examples of this include: the volume, Beyond Catholic: Heresy, Mysticism, and Apocalypse in Italian Culture (2014), reviewing figures such as Michelangelo, Ludovico Castelvetro, Ferrante Pallavicino, Vico, Fogazzaro, Zavattini, Eco, Baricco, Fo, Fallaci, Morselli, Volponi, and Wu Ming; the 2015 Special Issue of The Italianist devoted to Self-Reflection in Italian Literature, as well as the 2017 one on Realisms and Idealisms in Italian Culture, 1300-2017; and the volume Resistance in Italian Culture from Dante to the Twenty-First Century (2019), covering figures such as Dante, Bembo, Michelangelo, Leopardi, Ippolito Nievo, Palazzeschi, Bontempelli, Pasolini, Carlo Levi, and Elena Ferrante, to name but a few. ${ }^{36}$ In these publications, authors are placed together and aligned with one another in a new ontological, literary space. Such proximity is refreshing and dynamic, and opens up new lines of enquiry.

\section{Novecento and the Twenty-First Century}

For studies in the Novecento and the twenty-first century, too, literary cultures are alive and kicking. Literary texts still play a central role, with important critical editions and close

Lands (Liverpool: Liverpool University Press, 2017); Fabrizio De Donno, Italian Orientalism: Nationhood, Cosmopolitanism and the Cultural Politics of Identity (Oxford: Peter Lang, 2019).

${ }^{35}$ The Formation of a National Audience in Italy, 1750-1890: Readers and Spectators of Italian Culture, ed. by Gabriella Romani and Jennifer Burns (Madison, NJ: Fairleigh Dickinson University Press, 2017); The Printed Media in Fin-de-Siècle Italy: Publishers, Writers, and Readers, ed. by Jennifer Burns, Ann Hallamore Caesar and Gabriella Romani (London: Legenda, 2011).

${ }^{36}$ In order: Beyond Catholic: Heresy, Mysticism, and Apocalypse in Italian Culture, ed. by Fabrizio De Donno and Simon Gilson (New York: Palgrave Macmillan, 2014); SelfReflection in Italian Literature, ed. by Olivia Santovetti, The Italianist, 35.3 (2015); Realisms and Idealisms in Italian Culture, 1300-2017, ed. by Brendan Hennessey, Laurence E. Hooper, and Charles L. Leavitt IV, The Italianist, 37.3 (2017); Resistance in Italian Culture from Dante to the Twenty-First Century, ed. by Ambra Moroncini, Darrow Schecter, and Fabio Vighi (Florence: Cesati, 2019). The latter volume arose from the Society of Italian Studies themed conference at the University of Sussex (April 2018). 
readings guided by philological and literary historicist methodologies. ${ }^{37}$ There are also numerous studies of single poets and prose writers, based on linguistic and stylistic analyses and enquiries into the authors' themes and fictional strategies. The multilingual Amelia Rosselli, among the poets, has been the object of a series of important studies: Emanuela Tandello, Daniela La Penna, and Sara Sermini have all published on Rosselli's language and style, or discussed the themes of poverty and madness in her works. ${ }^{38}$ Their respective studies provide further examples of how the mobility of researchers, as mentioned earlier, is now reflected widely in transnational intersections between scholars based outside Italy, and Italian publishing houses.

Among prose writers, so-called 'Ferrante fever' has surrounded the work of Elena Ferrante. ${ }^{39}$ A major study of The Works of Elena Ferrante. Reconfiguring the Margins (2016), applies a feminist and gender approach to the writer. Multiple Ferrante-related events also testify to the 'fever': a public-oriented literary day in Leeds on 'Ferrante Fever' (October 2016), organised by Olivia Santovetti, one of the most vocal experts on Ferrante in the UK; and scholarly meetings at the University of Naples, Federico II ('Di Napoli non ci si libera facilmente. Per Elena Ferrante', April 2017), and at Durham University ('Elena Ferrante in a Global Context', June 2019), both with contributions from scholars based within and outside Italy. In addition, the workshop 'Elena Ferrante, Authorship and Style: A Conversation Between Digital Humanities and Literary Criticism', was held at University College Cork (December 2019), led by Maciej Eder and Olivia Santovetti.

Scholars considering literary influences and receptions in a transnational perspective work in both directions, examining intertextuality of Italian texts in relation to non-Italian literatures, and investigating how non-Italian authors have been received in the peninsula, ${ }^{40}$

\footnotetext{
${ }^{37}$ See for example the critical edition of Carlo Emilio Gadda, Eros e Priapo. Versione originale, ed. by Paola Italia and Giorgio Pinotti (Milan: Adelphi, 2016), and the collection of close readings in Le forme dell'analisi testuale. Sette letture novecentesche, ed. by Pietro Benzoni and Dirk Vanden Berghe (Florence: Cesati, 2018).

${ }^{38}$ Daniela La Penna, 'La promessa d'un semplice linguaggio'. Lingua e stile nella poesia di Amelia Rosselli (Rome: Carocci, 2013); Sara Sermini, 'E se paesani / zoppicanti sono questi versi'. Povertà e follia nell'opera di Amelia Rosselli (Florence: Olschki, 2019); Emanuela Tandello, Amelia Rosselli. La fanciulla e l'infinito (Rome: Donzelli, 2007). On Rosselli, see also Stefano Giovannuzzi's Amelia Rosselli. Biografia e poesia (Novara: Interlinea, 2016). ${ }^{39}$ See Grace Russo Bullaro and Stephanie V. Love, 'Introduction: Beyond the Margins: "Ferrante Fever" and Italian female writing', in The Works of Elena Ferrante. Reconfiguring the Margins, ed. by Grace Russo Bullaro and Stephanie V. Love (London: Palgrave, 2016), pp. 1-12.

${ }^{40}$ For the first, see for example Stefano Evangelista, 'La diffusione dell'opera fogazzariana nel mondo anglosassone: elaborazione romanzesca, traduzione e ricezione critica', Italian
} 
while those working on translation practices have focused on authors' word choices, metres, translingualism, identity construction, the history of publishing, politics, and censorship. ${ }^{41}$

Archives remain an important source for scholars to tap, and have been used to uncover unpublished letters and documents and reassess the work of single authors and canonical critical texts. ${ }^{42}$ Following the 'archival turn' that regards archives not just as repositories to preserve the objects and immobile traces of our past, but as subjects of new enquiry, and as institutions and practices to explore intellectual processes and networks, recent scholarship has looked at the role played by periodicals and publishing houses in Italian twentieth-century literary cultures. In particular, the AHRC-funded project, Mapping Literary Space: Literary Journals, Publishing Firms, Intellectuals in Italy 1940-1960 (2012-15), looked at 'the patterns of organization, cultural activity, and aesthetic programme of literary intellectual networks in

Studies, 73.4 (2018), 377-92; ‘International Intertexuality’, Part II of Goliarda Sapienza in Context: Intertextual Relationships with Italian and European Literature, ed. by Alberica Bazzoni, Emma Bond, and Katrin Wehling-Giorgi (Madison, NJ: Fairleigh Dickinson University Press, 2016). For our second field, see Marco Pioli, 'L'immaginario spagnolo di Leonardo Sciascia: genealogie mediterranee', Italian Studies, 74.4 (2019), 427-41; Giuliana Pieri, 'The Critical Reception of Tennyson in Italy', and 'Sleeping Beauties and Femmes Fatales: Tennyson, Gabriele D'Annunzio and Italian Pre-Raphaelitism', in The Reception of Alfred Tennyson in Europe, ed. by Leonée Ormond (London: Bloomsbury, 2016), pp. 85-104 and 105-24 respectively; Interprétations de la pensée du soupçon au tournant du XIX siècle. Lectures italiennes de Nietzsche, Freud, Marx, ed. by Elena Bovo, Antonella Braita, and Alberto Brambilla (Besançon: Presses Universitaires de Franche-Comté, 2013).

${ }^{41}$ See Nicola Gardini, 'An Ancient Soul in a New Body: Giovanni Pascoli’s Homeric Translations', Italian Studies, 66.1 (2011) 59-75; Daniela La Penna, 'Authoriality in Poetic Translation: the Case of Amelia Rosselli's Practice', Translation Studies, 7.1 (2014), 66-81; Eliana Maestri, Translating the Female Self Across Cultures. Mothers and Daughters in Autobiographical Narratives (Amsterdam: John Benjamins, 2018); Mila Milani, 'The Role of Translation in the History of Publishing: Publishers and Contemporary Poetry Translation in 1960s Italy', Translation Studies, 10.3 (2017), 296-311; Mila Milani 'Translation and Ideology in Post-war Italy: Left-wing Publishers and the Italian Communist Party', Twentieth Century Communism, 12 (2017) 62-87; Christopher Rundle, Publishing Translations in Fascist Italy (Bern: Peter Lang, 2010); Caterina Sinibaldi, 'Il nonsense del regime. Tradurre Alice durante il ventennio fascista', ll lettore di provincia, 138 (2012), Special Issue on I dilemmi del traduttore di nonsense, ed. by Franco Nasi and Angela Albanese, 65-80. On literature of the ventennio, not only in translation, see for example Guido Bonsaver, Mussolini censore: Storie di letteratura, dissenso e ipocrisie (Rome: Laterza, 2013). ${ }^{42}$ Michele Ronchi Stefanati, “Intonare lo strumento di un altro italiano". Il carteggio tra Gianni Celati e l'Einaudi (1966-1979)', Italian Studies, 72.3 (2017), 309-22; Beatrice Sica, 'Parigi 1929-1932 e oltre', in Paola Masino, ed. by Beatrice Manetti (Milan: Fondazione Arnoldo e Alberto Mondadori, 2016), pp. 109-33; Sica, L'Italia magica di Gianfranco Contini. Storia e interpretazione (Rome: Bulzoni, 2013); Katia Pizzi, 'Pinocchio and the Mechanical Body. Luciano Folgore's Papers at the Getty Research Institute Library', in Pinocchio, Puppets and Modernity. The Mechanical Body, ed. by Katia Pizzi (New York: Routledge, 2011), pp. 135-62. 
Italy' in the period 1940-1960. A number of important outputs resulted from the project, including the 2018 Special Issue of Italian Studies on Continuity and Rupture in the Italian Literary Field 1926-1960. ${ }^{43}$

When speaking of literary cultures, thematic approaches remain a privileged avenue for twentieth-century Italian studies, with war being lately one of the most widely explored, due to the centenary of World War I. ${ }^{44}$ Work has also been explored as a topic, with contributions, in this case, mostly from outside the UK. ${ }^{45}$ Alongside themes, literary genres or modes are still much considered, with special attention paid to science fiction; apocalyptic, utopian, dystopic, and postmodern narratives; and the fantastic. ${ }^{46}$ For the fantastic, a remarkable though

${ }^{43}$ Italian Studies, 73.2 (2018), Special Issue edited by Daniela La Penna, Francesca Billiani, and Mila Milani. For more information on the project and a complete list of its outputs, see: https://gtr.ukri.org/project/56ECDDCB-3EBB-441F-8D36-0E58542B2B9E. See also Daniela La Penna, 'Italian Literary Archives: Legacies and Challenges', in The Future of Literary Archives: Diasporic and Dispersed Collections at Risk, ed. by David C. Sutton and Anne Livingstone (Leeds: Arc Humanities Press-Amsterdam University Press, 2018), pp. 89-101. ${ }^{44}$ Among the innumerable publications in this area, some of those most largely centred on literary cultures were: Raccontare la guerra. I conflitti bellici e la modernità, ed. by Nicola Turi (Florence: Firenze University Press, 2017); The Great War and the Modernist Imagination in Italy, ed. by Luca Somigli and Simona Storchi, Special Issue of Annali d'italianistica, 33 (2015); L'image du soldat au XX siècle, ed. by Stefano Magni, Special Issue of Italies, 19 (2015); Les écrivains italiens et la Grande Guerre, ed. by Christophe Mileschi, Special Issue of Narrativa, hors série (2010). See also Selena Daly, Italian Futurism and the First World War (Toronto: University of Toronto Press, 2016), and, for a different war and perspective: Silvia Ross, 'Travel, Conflict, and Alterity: Representations of World War II Italy in Eric Newby and Iris Origo', Studies in Travel Writing, 16.2 (2012), 149-62.

${ }^{45}$ See Letteratura e azienda: rappresentazioni letterarie dell'economia e del lavoro nell'Italia degli anni 2000, ed. by Silvia Contarini, Special Issue of Narrativa, 31-32 (2010); Daniele Fioretti, Carte di fabbrica. La narrativa industriale in Italia (1934-1989) (Pescara: Tracce, 2013); From 'Otium' and 'Occupatio' to Work and Labor in Italian Culture, ed. by Norma Bouchard and Valerio Ferme, Special Issue of Annali d'Italianistica, 32 (2014); Monica Jansen, 'Narrazioni della precarietà: il coraggio dell'immaginazione', Part II of Scritture di resistenza. Sguardi politici dalla narrativa italiana contemporanea, ed. by Stefano Jossa and Claudia Boscolo (Rome: Carocci, 2014); Il padrone nella letteratura italiana del Novecento, ed. by Stefano Lazzarin, Special Issue of La Critica Sociologica, 199.3 (2016); Il lavoro e il suo racconto: sociologia e letteratura nell'analisi del mercato del lavoro, ed. by Stefano Lazzarin and Giustina Orientale Caputo, sezione monografica, Sociologia del Lavoro, 153.1 (2019), pp. 33-181. See also the contributions in Part II of The Years of Alienation in Italy. Factory and Asylum Between the Economic Miracle and the Years of Lead, ed. by Alessandra Diazzi and Alvise Sforza Tarabochia (Cham, Switzerland: Palgrave Macmillan, 2019).

${ }^{46}$ See, for example, Simone Brioni and Daniele Comberiati, Italian Science Fiction. The Other in Literature and Film (New York: Palgrave Macmillan, 2019); Florian Mussgnug, 'Rome in Ruins Revisited: Mario Soldati's The Emerald and Catastrophic Futurism', in Rome: Modernity, Postmodernity and Beyond, ed. by Lesley Caldwell and Fabio Camilletti 
somewhat non-canonical enterprise is Stefano Lazzarin's recent Il fantastico italiano. Bilancio critico e bibliografia commentata (dal 1980 a oggi), with a long introductory essay on theories and criticism regarding the Italian fantastic in the last thirty-five years, followed by an impressive 'Repertorio bibliografico ragionato sul fantastico italiano (dal 1980 ad oggi)', presenting collaborations between scholars again from a range of countries. ${ }^{47}$ Much debate in Italy was also caused by the so-called nuovo realismo as a way of reacting to postmodernism. ${ }^{48}$ Following this wave, crime fiction too has received much attention, and been used to explore issues such as violence, urban space, gender, Italian politics, and society. ${ }^{49}$ Both nuovo realismo and crime fiction are strictly related to impegno (see below).

(Cambridge: Legenda, 2018), pp. 37-52; Fabio Camilletti, Italia lunare: gli anni Sessanta e l'occulto (Oxford: Peter Lang, 2018); the section on 'Fantastico femminile e nuove prospettive di ricerca sul fantastico italiano', ed. by Beatrice Laghezza, in the journal Bollettino '900 1-2 (2018), https://boll900.it/2018-i/; Daniele Fioretti, Utopia and Dystopia in Postwar Italian Literature. Pasolini, Calvino, Sanguineti, Volponi (London: Palgrave Macmillan, 2017); Gillian Ania, 'Bypassing the End: Three Contemporary Interpretations of Apocalypse', Italian Studies, 69.2 (2014), 283-300; Pierpaolo Antonello, "How I learned to stop worrying about the bomb." Minaccia nucleare, apocalisse e tecnocritica nella cultura italiana del secondo Novecento', The Italianist, 33.1 (2013), 89-119; Le devenir postmoderne. La sensibilité postmoderne dans les littératures italienne et portugaise, ed. by Ana Maria Binet and Martine Bovo Romoeuf (Brussels: Peter Lang, 2013).

${ }^{47}$ Stefano Lazzarin et al., Il fantastico italiano. Bilancio critico e bibliografia commentata (dal 1980 a oggi) (Florence: Le Monnier, 2016).

${ }^{48}$ See Allegoria, 57 (2008), and, most recently, Encounters with the Real in Contemporary Italian Literature and Cinema, ed. by Loredana Di Martino and Pasquale Verdicchio (Newcastle: Cambridge Scholars Publishing, 2017).

${ }^{49}$ Marco Paoli, 'Patriarchal Structural Violence and Narrative Space: The Reader's Process of Identification with Female Characters in Italian Crime Fiction', Spunti e ricerche, 33 (2018), 45-63; Barbara Pezzotti, Investigating Italy's Past through Historical Crime Fiction, Films and TV Series. Murder in the Age of Chaos (New York: Palgrave, 2016); Marco Paoli, Giorgio Scerbanenco: Urban Space, Violence and Gender Identity in Post-War Italian Crime Fiction (Brussels: Peter Lang, 2016); Marco Amici, 'The Black Album Reloaded. Conversazione con Massimo Carlotto' in Cattivi. Cattivissimi. Cattivi? Sulle tracce di eroi criminali nelle narrazioni di genere. UK, USA, Italia, ed. by Emanuele Croci, Emanuele Monegato, and Anna Pasolini (Milan: Mimesis, 2016), pp. 203-12; Alessia Risi, 'Approaches to Gender: Grazia Verasani's Giorgia Cantini Series', in Out of Deadlock. Female Emancipation in Sara Paretsky's V. I. Warshawski Novels, and her Influence on Contemporary Crime Fiction, ed. by Enrico Minardi and Jennifer Byron (Newcastle: Cambridge Scholars Publishing, 2015), pp. 117-133; Barbara Pezzotti, Politics and Society in Italian Crime Fiction. A Historical Overview (Jefferson, NC: McFarland, 2014); Marco Amici, 'La narrativa a tema criminale: poliziesco e noir per una critica politica', Part III of Scritture di resistenza. Sguardi politici dalla narrativa italiana contemporanea, ed. by Stefano Jossa and Claudia Boscolo (Rome: Carocci, 2014); Barbara Pezzotti, The Importance of Place in Contemporary Italian Fiction: A Bloody Journey (Madison, NJ: Fairleigh Dickinson University Press, 2012); Marco Amici and Massimo Carlotto, The Black Album. Il 
The explosion of interdisciplinarity is even more apparent in studies on the avant-garde, with Futurism, interdisciplinary by its nature, at the forefront. Publications here abound; we will only mention two of the most recent ones: the Handbook of International Futurism, which examines comparatively all media and countries in which Marinetti's movement exercised its influence; and Katia Pizzi's book on Italian Futurism and the Machine, which looks at the Futurist machine cult through literature, visual arts, photography, film, music, and performing arts. ${ }^{50}$ Historical as well as neo-avant-garde movements were widely addressed in two linked projects funded by the AHRC, Interdisciplinary Italy 1900-2015: art, music, text (2012-14), which evolved into Interdisciplinary Italy 1900-2020; interart/intermedia (2015-17). In both, an academic team collaborated with museum curators, practicing artists, and other nonacademic partners, to discuss inter-art and transmediality. ${ }^{51}$

The influence of Cultural Studies can also be widely seen in studies that use literature, among other artistic and non-artistic products of many kinds, to explore cultural memory, politics, ideology, and social constructions. Following the publication of Postmodern Impegno: Ethics and Commitment in Contemporary Italian Culture (2009), in the last decade many studies have also looked, specifically, at the impegno of single writers, of intellectuals as a class, and of journals and publishing houses. ${ }^{52}$ The political engagement of intellectuals in the

Noir tra cronaca e romanzo (Rome: Carocci, 2012); Italian Crime Fiction, ed. by Giuliana Pieri (Cardiff: University of Wales Press, 2011).

${ }^{50}$ Handbook of International Futurism, ed. by Günter Berghaus and Selena Daly (Berlin: De Gruyter, 2019); Pizzi, Italian Futurism and the Machine (Manchester: Manchester University Press, 2019).

${ }^{51}$ See the Mini-Special Issue on Cultural Studies published in this journal (Italian Studies, 74.4 (2019), 329-80), with an editors' introduction by Clodagh Brook, Florian Mussgnug, and Giuliana Pieri: 'Open Works: Italy's Creative Intermediality', pp. 329-30; Transmedia. Storia, memoria e narrazioni attraverso i media, ed. by Clodagh Brook and Emanuela Patti (Milan: Mimesis, 2014); Clodagh Brook and Giuliana Pieri, 'Interdisciplinary Italy: Disciplines, Inter-disciplines and Transmediality', and Emanuela Patti, 'Letteratura oltre i confini del libro. Storie e narrazioni italiane attraverso i media', both in Lingua e cultura italiana nei mass media. Uno sguardo interdisciplinare, ed. by Marco Gargiulo (Rome: Aracne, 2014), pp. 13-31 and 33-57 respectively; and the website www.interdisciplinaryitaly.org.

52 Postmodern Impegno: Ethics and Commitment in Contemporary Italian Culture, ed. by Pier Paolo Antonello and Florian Mussgnug (Oxford: Peter Lang, 2009). See for example Daniele Fioretti, 'Pavese e l'engagement postbellico: da I dialoghi col compagno a La casa in collina', in Cesare Pavese a San Francisco: incontro per la celebrazione del centenario della nascita. Atti del Congresso 24-25 ottobre 2008, ed. by Christopher Concolino (Florence: Cesati, 2011), pp. 53-59; Pier Paolo Antonello, Dimenticare Pasolini. Intellettuali e impegno nell'Italia contemporanea (Milan: Mimesis, 2012); the Special Issue of The Italianist, 32.1 (2012) devoted to Meneghello: Fiction, Scholarship, Passione Civile, ed. by Daniela La Penna; Stefano Jossa and Claudia Boscolo, 'Finzioni metastoriche e sguardi politici della 
social and political arena is something that has been often uncomfortably present since at least the time of Dante, but it is fair to say that in Italy it became particularly relevant in the twentieth century. Hence, it is unsurprising that most studies have focused on the fascist and post-World War II periods up to today. Within this arc of scholarly production, the Years of Lead constitute almost a sub-field in their own right. ${ }^{53}$ So too are studies on Pasolini, one of the most prominent and still influential examples of impegno, widely read and re-discussed through various lenses, including those of biopolitics ${ }^{54}$ and with the centenary of his birth coming up in 2022, more contributions on Pasolini are certainly to be expected. However, a cross-century approach has also been adopted: to the above-mentioned volume, Resistance in Italian Culture from Dante to the Twenty-First Century, we may here add the 2016 Special Issue of Annali d'Italianistica devoted to Speaking Truth to Power from Medieval to Modern Italy. ${ }^{55}$

narrativa contemporanea', Part I of Scritture di resistenza. Sguardi politici dalla narrativa italiana contemporanea, ed. by Stefano Jossa and Claudia Boscolo (Rome: Carocci, 2014); Mila Milani, 'Impegno, National and Transnational Identities in Il Politecnico and Sud (1945-1947)', Modern Italy, 21.2 (2016), 157-170; Mila Milani, 'From Risorgimento to Il Politecnico: Impegno and Intellectual Networks in the Einaudi Publishing House, 1945', Journal of Modern Italian Studies, 21.1 (2016), 35-49; Beatrice Sica, 'Alfonso Gatto e l'operetta buffa dell'uomo a cavallo', Sinestesie. Rivista di studi sulle letterature e le arti europee, 14 (2016), 403-07, in the Special Issue on Un poeta in prosa. Alfonso Gatto. Cronache del piacere (1957-1958), ed. by Epifanio Ajello; Beatrice Sica, 'Italo Calvino prima e dopo la guerra: il fascismo, Ariosto e l'uomo a cavallo', in Raccontare la guerra, pp. 127-152; Emanuela Patti and Giuliana Pieri, 'Technological Poetry: Interconnections between Impegno, Media, and Gender in Gruppo 70 (1963-1968)', Italian Studies, 72.3 (2017), 323-37. For more on journals and impegno, see also the 2018 Special Issue of Italian Studies on Continuity and Rupture in the Italian Literary Field 1926-1960.

${ }^{53}$ See at least Raffaele Donnarumma, 'Storia, immaginario, letteratura: il terrorismo nella narrativa italiana 1969-2010', in Per Romano Luperini, ed. by Pietro Cataldi (Palermo: Palumbo, 2010), pp. 438-65; Gabriele Vitello, L'album di famiglia: gli anni di piombo nella narrativa italiana (Massa: Transeuropa, 2013); Ermanno Conti, Gli 'anni di piombo' nella letteratura italiana (Ravenna: Longo, 2013); Ruth Glynn, Women, Terrorism and Trauma in Italian Culture (New York: Palgrave Macmillan, 2013); David Ward, Contemporary Italian Narrative and 1970s Terrorism. Stranger than Fact (New York: Palgrave Macmillan, 2017). ${ }^{54}$ See, at least, Emanuela Patti, Pasolini After Dante. The 'Divine Mimesis' and The Politics of Representation (Oxford: Legenda, 2016); Davide Messina, Pasolini et son chant du signe. Écriture, cinéma, musique (Paris: L’Harmattan, 2018); Marco Antonio Bazzocchi, 'Costellazione di immagini: tracce di Walter Benjamin in Pasolini, tra la Divina Mimesis e La Rabbia', Studi pasoliniani, 13 (2019), 13-27; 'Petrolio' 25 anni dopo. (Bio)politica, eros e verità nell'ultimo romanzo di Pier Paolo Pasolini, ed. by Carla Benedetti, Davide Luglio, and Manuele Gragnolati (Rome: Quodlibet, 2020).

${ }^{55}$ Speaking Truth to Power from Medieval to Modern Italy, ed. by Jo Ann Cavallo and Carlo Lottieri, Special Issue of Annali d'Italianistica, 34 (2016). 
Other intersections among disciplines are always possible: literature and gender remain an important duo; ${ }^{56}$ of course, feminism, women's, gender, and queer studies have long been used by scholars in Italian Studies going far beyond the literary field or Italy. Going back to literary cultures, they can be looked at through the lenses of virtually any discipline, with all fields of inquiry, old and new, being admitted: psychoanalysis, aesthetics and philosophy, architecture, biopolitics, ecocriticism and environmental studies, animal studies, and the posthuman. ${ }^{57}$ The list is, of course, not exhaustive.

As a result of migratory flows to the peninsula and the crisis of migrants in Europe, literature, together with other cultural practices of signification, has also been used to explore

${ }^{56}$ Italian Heroines: Literature, Gender, and the Construction of the Nation, ed. by Serena Alessi and Stefano Jossa, Special Issue of The Italianist, 39.3 (2019); Women and Violence in Italian Literature, ed. by Gregoria Manzin and Barbara Pezzotti, Special Issue of Spunti e ricerche, 33 (2018); Mascolinità nella letteratura italiana contemporanea, ed. by Manuela Spinelli, Special Issue of Narrativa, 40 (2018); Alessia Risi, 'Elena Ferrante's Neapolitan Novels: Retelling History through Gendered Fiction', Journal of Romance Studies, 18.3 (2018), 317-40; Women and the Public Sphere in Modern and Contemporary Italy. Essays for Sharon Wood, ed. by Simona Storchi, Marina Spunta, and Maria Morelli (Leicester: Troubadour, 2017); Charlotte Ross, Eccentricity and Sameness: Discourses on Lesbianism and Desire between Women in Italy, 1860s-1930s (Oxford: Peter Lang, 2015); Nicola Gardini, 'Dante as a Gay Poet', in Metamorphosing Dante. Appropriations, Manipulations, and Rewritings in the Twentieth and Twenty-First Centuries, ed. by Manuele Gragnolati, Fabio Camilletti, and Fabian Lampart (Vienna: Turia + Kant, 2011), pp. 61-74.

${ }^{57}$ Alessandra Diazzi, 'A Lapsus, My Little Readers: The Presence of Psychoanalysis in Giorgio Manganelli's Pinocchio: un libro parallelo', The Italianist, 39.1 (2019), 64-81; Alvise Sforza Tarabochia, 'The Aphanisis of the Pirandellian Subject', Italian Studies, 68.1 (2013), 123-37; Giuseppe Stellardi, 'The Point of Time: Structures of Temporality in Primo Levi's Se questo è un uomo', The Modern Language Review, 114.4 (2019), 700-19; Beatrice Sica, 'Le sigarette di Bontempelli, neosofista tra Croce e Savinio', in Il racconto e il romanzo filosofico nella modernità, ed. by Anna Dolfi (Florence: Firenze University Press, 2013), pp. 135-56; Francesca Billiani and Laura Pennacchietti, Architecture and the Novel under the Italian Fascist Regime (New York: Palgrave Macmillan, 2019); the Special Issue, Urban Space and the Body, ed. by Silvia Ross and Giulio Giovannoni, for Annali d'italianistica, 37 (2019); Federica Pedriali, 'Nella lettera della storia: per una lettura biopolitica della guerra di Gadda', in Rappresentazione e memoria. La 'quarta' guerra d'indipendenza, ed. by Claudio Gigante (Florence: Cesati, 2017), pp. 93-111; Niccolò Scaffai, Letteratura e ecologia. Forme e temi di una relazione narrativa (Rome: Carocci, 2017); Ecosistemi letterari. Luoghi e paesaggi nella finzione novecentesca, ed. by Nicola Turi (Florence: Firenze University Press, 2016); Monica Seger, Landscapes in Between: Environmental Change in Modern Italian Literature and Film (Toronto: University of Toronto Press, 2015); Thinking Italian Animals. Human and Posthuman in Modern Italian Literature and Film, ed. by Deborah Amberson and Elena Past (New York: Palgrave Macmillan, 2014); Posthumanism in Italian Literature and Film. Boundaries and Identity, ed. by Enrica Ferrara (New York: Palgrave Macmillan, 2020). 
issues of space, home, identity, memory, the local, the global, and the transnational. ${ }^{58}$ These studies can be seen as a strand of a much larger wave that has gained momentum in the last decade, and for which Italian literary cultures have intersected with migration and postcolonial studies. In this context, the AHRC-funded research project, Transnationalizing Modern Languages: Mobility, Identity and Translation in Modern Italian Cultures (TML: 2014-17), was a very important catalyst, bringing together researchers based across four UK universities. The alertness to transnational exchange fostered within the project is evident also in Charles Burdett's important book examining Italy's relationship with Islam and the Islamic world today. ${ }^{59}$

We would like to close this overview of the state of literary cultures in Italian Studies by mentioning La letteratura italiana al tempo della globalizzazione, a Special Issue of contemporary Italian literature journal Narrativa. The issue collects contributions authored by a vast range of scholars, discussing the position of Italian literature in a global context. ${ }^{60}$

${ }^{58}$ See the section 'Beyond Borders: Transnational Italy', in Italian Studies, 74.4 (2019), 38196; Charles Burdett, 'Transnational Time: Reading Post-War Representations of the Italian Presence in East Africa', Italian Studies, 73.3 (2018), 274-88; Jennifer Burns, 'Mapping Transnational Subjecthood: Space, Affects and Relationality in Recent Transnational Italian Fictions', California Italian Studies, 8.2 (2018), 1-17; Destination Italy: Representing Migration in Contemporary Media and Narrative, ed. by Emma F. Bond, Guido Bonsaver, and Federico Faloppa (Oxford: Peter Lang: 2015); Giuliana Benvenuti, 'Who Needs "Italianness"? Postcolonial and Migration Italian Literature', in Identity. Concepts, Theories, History and Present Realities (A European Overview), ed. by Maria Manuel Baptista (Coimbra: Grácio, 2015), pp. 121-38; Giuliana Benvenuti, 'Memoria e métissage nel romanzo italiano postcoloniale e della migrazione', in Memoria storica e postcolonialismo: il caso italiano (Brussels: Peter Lang, 2015), pp. 115-38; Jennifer Burns, 'Lupus in fabula: The workings of fear in Italian Migration Narratives', Italian Studies, 68.3 (2013), 429-48; Jennifer Burns, Migrant Imaginaries: Figures in Italian Migration Literature (Oxford: Peter Lang, 2013); Il confine liquido: rapporti letterari e interculturali fra Italia e Albania, ed. by Emma F. Bond and Daniele Comberiati (Nardò: Besa, 2013); Silvia Ross, 'Space, Place, and Italian Literature: Writing a Region', Italian Studies, 68.3 (2013), 448-59; Coloniale e postcoloniale nella letteratura italiana degli anni 2000, ed. by Silvia Contarini, Giuliana Pias, Lucia Quaquarelli, Special Issue of Narrativa, 33-34 (2012); Jennifer Burns, 'Language and its Alternatives in Italophone Migrant Writing', and Rhiannon Noel Welch, 'Intimate Truth and (Post)colonial Knowledge in Shirin Ramzanali Fazel's Lontano da Mogadiscio', in National Belongings: Hybridity in Italian Colonial and Postcolonial Cultures, ed. by Derek Duncan and Jacqueline Andall (Oxford: Peter Lang, 2010), pp. 127-48 and 215-33 respectively.

${ }^{59}$ Charles Burdett, Italy, Islam and the Islamic World: Representations and Reflections from 9/11 to the Arab Uprisings (Oxford: Peter Lang, 2016). Burdett led the TML project, together with Jennifer Burns, Derek Duncan, and Loredana Polezzi:

https://www.transnationalmodernlanguages.ac.uk/.

${ }^{60}$ La letteratura italiana al tempo della globalizzazione, ed. by Silvia Contarini, Margherita Marras, Giuliana Pias, and Lucia Quaquarelli, Special Issue of Narrativa, 35-36 (2014). 
Globalisation can be seen in diverse and even opposite ways, as threatening local identities, or as transforming them through creolisation, but in the end, porosity seems inevitable. At a time of political and social uncertainty both within and beyond the academy, when the UK is in the process of formally leaving the European Union, it is good to remind ourselves that literature, and Italian literature in particular, cannot but be open, and look beyond national borders.

\section{The Beauty and the Politics}

We hope that this overview, however incomplete and simplified, gives an idea of the rich and multidisciplinary intersections that enliven scholarship on Italian literary cultures today. Indeed, the stimulus for exchange is everywhere: the expanding networks of Italianists working inside and outside the peninsula; the flow of young Italian scholars educated in Italy, who settle and work abroad within an international academic job market, but who keep strong ties with their country of origin, and sometimes move back after their years away; the general mobility of researchers, especially at postdoctoral and early career levels, through various forms of national and European funding; and the international collaborations encouraged by universities everywhere, and supported even through local small grants. All of this means that scholars and academic traditions get mixed up, producing very fruitful exchanges.

Scholars in literary cultures have the maximum freedom to treat literature as they want, but one thing is certain: alongside literary research conducted in a more traditional vein, the majority of studies today see literature as a social construct whose reasons are intrinsically connected with power structures that are in place at a certain time. As Terry Eagleton puts it:

Any belief that the study of literature is the study of a stable, well-definable entity, as entomology is the study of insects, can be abandoned as a chimera. [...] There is no such thing as a literary work or tradition which is valuable in itself [...]. 'Value' is a transitive term: it means whatever is valued by certain people in specific situations, according to particular criteria and in the light of given purposes. ${ }^{61}$

Today this is well spelled out in literary studies. The current attention to issues of gender, migration, postcolonialism, biopolitics, ecology, the environment, urban space, work, and politics in today's literary cultures tells us how much these issues are at stake in the world in

${ }^{61}$ Terry Eagleton, Literary Theory. An Introduction, 2nd edn (London: Blackwell, 2003), pp. 9-10. 
which we live. Literature reflects them, because it is a product of this world, and our studies of literature also speak of our concerns. However, these processes of reflection - literature reflecting the world, and ourselves reflecting on literature - are much more complex. Indeed, even if, to use Eagleton's words again, 'the so-called "literary canon", the unquestioned "great tradition" of the "national literature", has to be recognized as a construct, fashioned by particular people for particular reasons at a certain time', the fact that certain works have remained there for centuries to form our idea of what we have long been calling literature beyond national canons - creates a dimension that cannot be reduced to the particularities of a certain time and space. ${ }^{62}$ Eagleton claims that 'Anything can be literature, and anything which is regarded as unalterably and unquestionably literature [...] can cease to be literature' ${ }^{63}$ yes, indeed, nothing is certain, but some works have been constituting the space of literature for quite a long time now, and we cannot stop seeing them as something that, while belonging to their own particular contexts and cultures, also transcend these contexts and cultures.

In modern critical discourse, it seems that we cannot escape moving between the two poles that Eagleton calls the ontological and the functional. The pendulum has definitely shifted lately toward the latter terms of these binomials. However, the problem for literary studies today is not so much where we lean, what we (scholars and teachers) consider literature to be, what we know we can do with it, or what we actually do with it, but the place that literature is given and assigned in our society. There seems to be a dichotomy between the richness and variety of the possible approaches to literary studies we can have - and which we have tried in part to illustrate here - and what we can do with literature, for example, in our teaching.

Noting the 'smaller and smaller actual influence of literature on common culture', the 'radically reduced enrolment in literature courses' in universities, and the 'rapid reduction of literature departments to service departments teaching composition and the rudiments of foreign languages and foreign cultures', Joseph Hillis Miller attributed the dimming of the future for literary studies, at least in the United States, to the turning of colleges and universities 'into trade schools [...] and institutions that have less and less place for the humanities', and, even more, to the 'new teletechnologies that are fast making literature obsolete'. 'Even many', he writes, 'who could teach literature, who were hired to do so, choose [...] to teach cultural

\footnotetext{
${ }^{62}$ Eagleton, p. 10.

${ }^{63}$ Eagleton, p. 9.
} 
studies instead' ${ }^{64}$ It is clear to everyone that we can no longer rely on the status that literature used to have; today, we are asked metaphorically to cook it with something else, and justify it as much as we can.

What kind of justifications can we find for literature? Here the ontological and the functional return, this time together, albeit still as distinct categories. Miller reaffirmed the aesthetic value of literature as ontological, when he wrote: a 'poem, like a rose, has no reason for being beyond itself. You can read it or not read it, as you like. It is its own end'. The pleasure it can give us, he suggests, is what makes it important. 'That importance [...] is something I should not even try to justify by its practical utility. If I do make that attempt, I am bound to fail' ${ }^{65}$ And yet, as we said, nowadays beauty seems unable to stand on its own. The ontological needs the functional.

Cultural studies taught us to see the politics behind literature. But what can literature teach us? If beauty is not enough, what else can we teach through literature? Miller thinks that literature can make us see behind politics: in a world 'inundated with a torrent of distortions and outright lies from politicians, the news media, and advertising on television and radio', literature can teach us how to resist: "Learning how to read literature "rhetorically" is primary training in how to spot such lies and distortions' ${ }^{66}$ Is that it? But where has beauty gone? In order to spot such distortions, one could probably do well enough with a handbook of rhetorical devices. Do we really need novels and poems for that?

In a recent article, Timothy Aubry wrote that 'politics and aesthetics often overlap, but their fit is not perfect'. This statement was offered in response to the increasing tendency he sees to ask the humanities to take sides, and to judge them based on the side they take. Aubry advocates for literature's aesthetic value:

To affirm literature's aesthetic value is to argue that it does something more than serve as an instrument for a particular politics, that the experiences it fosters are worth pursuing not only because they reaffirm our political views or further our ideological aims, but because they represent a mode of fulfilment - a quickening of our perceptions, a dilation of our temporal

${ }^{64}$ J. Hillis Miller, 'Should we read or teach literature now?', Anglia: Journal of English Philology, 129.1-2 (2011), pp. 7, 9.

${ }^{65}$ Miller, p. 9.

${ }^{66}$ Miller, p. 10. 
experiences, a revitalization of our thought and feeling — unavailable elsewhere. ${ }^{67}$

Among Italianists, Massimiliano Tortora argued the same, when he wrote that literature fosters 'un sano allenamento alla complessità', defends 'le istanze dell'intelligenza sequenziale', and allows people 'soprattutto di simbolizzare traumi ed eventi della vita, e più in generale allestire un vocabolario per le emozioni', thus contributing to the 'istituzione dell'io e rispetto dell'altro'. Tortora invites us to see 'la letteratura come un dispositivo di conoscenza e di crescita, con specificità e peculiarità proprie, che altre discipline non possono offrire. ${ }^{68}$

What should we do then with literature? We would never renounce the freedom and the broadened horizons that interdisciplinarity, with its politics, gave us: as readers and scholars, we were taken to lands that we could never imagine we could enter with our literary books; and we learned to read better. Yet, as teachers, we should also remember the beauty and power that are peculiar to literature; and that literature is useful in ways that we cannot predict, or dictate: ultimately, it is in the world of perceptions, thought, and emotions that our inner freedom lies.

${ }^{67}$ Timothy Aubry, 'Should Studying Literature Be Fun?', The Chronicle of Higher Education, 2 December 2018, https://www.chronicle.com/article/Should-Studying-Literature$\mathrm{Be} / 245235$.

${ }^{68}$ Massimiliano Tortora, 'I classici a scuola: tra dialogo e distanza', Allegoria, 75.1 (2017), 121-30 (pp. 126-28, 130). 